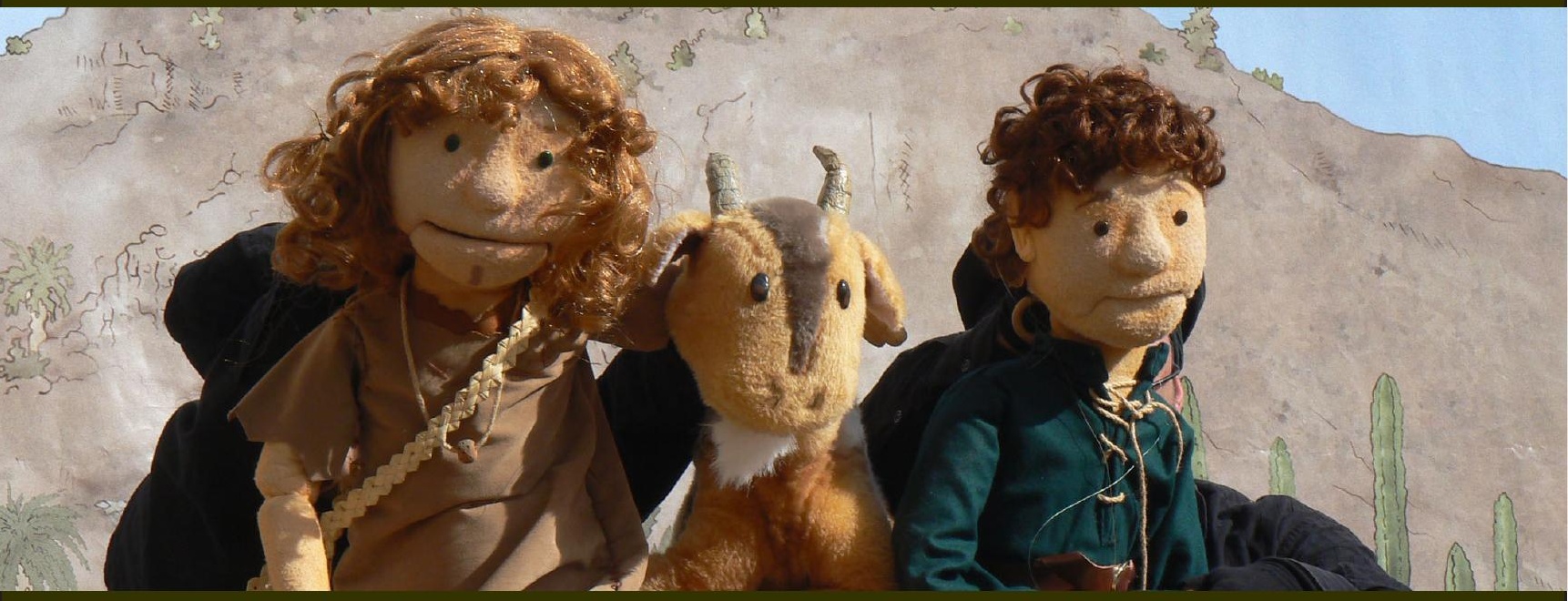

\title{
Editor:
}

Jaime Almansa Sánchez

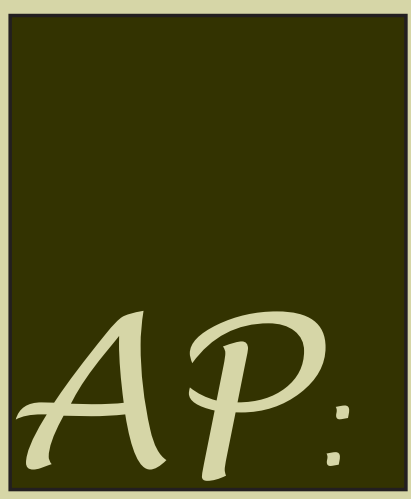

www.arqueologiapublica.es

Ontine Journat in Public Archaeology 


\title{
EDITORIAL
}

\section{The beginning of a new experience}

\author{
Jaime ALMANSA SÁNCHEZ, Editor \\ JAS Arqueología S.L.U.
}

One year ago I was starting a new archaeological company. I tried to translate my personal projects into commercial products and encountered my first dilemma in this new adventure: How can I ask for a public Archaeology from the private sector? This journal is one of the answers.

Beginnings are always hard even more in these times of crisis we are suffering. Fortunately, JAS Arqueología has survived its first year and the first volume of AP: Online Journal in Public Archaeology is here, overcoming the hardest stage of its short life.

First of all, I would like to apologize for the delay in the publication of this first volume, but if editing a journal is hard, doing it in our current conditions does not help to make it easier. Secondly, I cannot continue without thanking Elena Papagiannopoulou for her inestimable role as Assistant Editor. This would have never been possible without her work and support. And thirdly, I also need to thank all the authors who participate in this volume for trusting us and setting the basis of what we hope will be a reference publication in the field.

A few months ago I decided to start the history of this journal with a pre-editorial that set the aims and the philosophy of this project. In it, I tried to define my vision of Public Archaeology. It is not far from other attempts and just pretended to sum up the blurry ideas that still grow up in the field with a synthetic and concise sentence that could fit all of them. In essence, the aim is to build up a new resource for archaeologists, in which we can discuss and share ideas, experiences and concerns.

This first number represents the beginning of a new experience, mainly with the participation of young researchers who, like me, are concerned about different issues around Public Archaeology. 
If we had to propose a common topic for all the papers, it would be 'Education'. I like to say that all our problems could be solved with a better education, and most Public Archaeology activities have a bit of it in their essence. Using different tools, our aims converge on a better public understanding of Archaeology, and that is Education. Randomly (or maybe not that much), we will see this idea in all the papers of this first volume, starting with our cover image; Arminda.

One year ago I had the opportunity to meet Carmen Rodríguez, from Cueva Pintada, during a workshop in Addis Abeba. I was so shocked that even before starting the journal I knew I would like her to participate in something. She sent me the tales, some postcards and stickers and I definitely fell in love with Arminda. The first article of this volume is about the first steps of the project as well as its aims and results until now. I hope you will fall in love the same way I did, and do not forget to visit Cueva Pintada if you visit Gran Canaria.

The next three articles delve deeper in actual education. First, Sergio Moreno and Nicholas Márquez-Grant tour the last forty years of children activities, focusing on experiences in the United Kingdom and Spain. One of the issues that emerge is the lack of Archaeology in schools. This will be first analyzed by Amanda Erickson in her paper about outreach and education in Archaeology, and then complemented with Jessica Sutherland's paper. There, she exposes her activities with children in USA schools, which keep growing today in number and variety.

The last paper introduces a slight change in the topic, focusing on video games. So far, there is not an extensive bibliography about them, but their value as educational materials is unquestionable and has been underestimated. Daniel García-Raso will examine their value and possibilities for Archaeology through different titles.

Now is the moment to introduce a new section; Points of You. Here we would like to offer you an open place to express your views in an informal way. We want to know how you feel about Public Archaeology in your region, your country or yourself. The section will be launched by Marlon Pestana, a Brazilian archaeologist that, like me, looks for a Public Archaeology from the private sector in a country that appropriated its Heritage recently.

We did not have much time to collect reviews of events and books, but will have one, by Dru McGill, about the last book published by JAS Arqueología; The transforming ethical practice in Philippine 
archaeology, by Pamela Faylona. We encourage you to collaborate with us by sending us reviews of books, events, movies, music, trips, or whatever you consider that has something to do with Public Archaeology.

Five papers, one open letter and a review. That is all for this first volume. I would like to thank again all the people that have participated in it, and hope you all find these articles interesting and useful. The journal is open to everybody and you can participate in many different ways, from writing to commenting on Facebook.

So thank you all for helping make this real and I really hope you will enjoy this very first volume.

\section{$* * * * *$}

Before letting you continue, I would like to make 4 fast announcements:

\section{Call for debate:}

When I say 'commenting on Facebook' two lines above, I mean that we will open a discussion board on the papers where we can continue the debate and growth of the contents. Doubts, considerations, ideas... New topics are also welcome. In order to keep the journal alive between numbers, this is the best tool we can offer right now. I Hope you will participate in it.

\section{Call for papers:}

After Volume 1, we are expecting to publish Volume 2 in 2012. We have an open call for papers where you can submit them whenever you prefer. Anyway, our estimations for paper submissions go for September as a good deadline for each volume, if we want to be on time for January. We are willing to receive new papers soon to be able to work patiently. Any idea you might have, email us. Specifically if you have any doubt.

\section{Call for specials:}

We will also be publishing special issues focused on different topics. Our first call is for the AP Journal Special Issue titled "Public Archaeology in vast infrastructure works", for which we are looking for papers on the archaeology conducted in megaconstructions such as airports, undergrounds, highways, etc., from 
the perspective of Public Archaeology in any of its lines (politic and economic issues, education programs practiced, management, etc.). We encourage you to participate in it if you are in some way related to the project. If you have any doubt, once again, do not hesitate to write us.

We are also happy to accept any new proposal for other special issues that you can edit, or just drop to us. You can propose a topic and we will decide and agree the terms, always under the rules of the journal. So, if you have in mind a volume with a subject dealing with something related to Public Archaeology, please contact us and we will consider it.

\section{Call for donations:}

While JAS Arqueología is alive, it will take care of this journal. As you already know AP is a free-access journal and (al)so not for profit. Anyway, maintaining it is expensive, both in money and time invested. The philosophy of the journal is to provide the widest access at the lowest cost, but in order to increase the quality and efficiency of the content there is a need for funding that will depend on you.

This year we have to thank Giannis and Vicky for the first generous donation, which is helping a lot to ensure the near future of the journal. We will open a list of donors in the last page to thank everybody that is helping with their money and their time to make this project real.

Remember there are two ways of contribution:

-Direct donation via Paypal on our web page.

-Purchase of the paper version. There will be a fixed price of $30 €$. Just ask us. 


\section{AP: Ontine Journat in Public Archaeology}

Editor:

Jaime Almansa Sánchez

Email: almansasanchez@gmail.com

Assistant editor:

Elena Papagiannopoulou

Edited by:

JAS Arqueología S.L.U.

Website: www.jasarqueologia.es

Email: jasarqueologia@gmail.com

Address: Plaza de Arteijo 8, T-2, 28029 - Madrid (Spain)

--

Cover Image: Arminda, Guama y Fernandillo (Cueva Pintada)

Copyright (C) 2011 JAS Arqueología S.L.U. (edition) \& Authors (content)

ISSN: $2171-6315$

Quotation:

Almansa, J. 2011. Editorial: The beginning of a new experience. AP Journal Vol. 1, 1-4.

AP Journal is a new peer-reviewed journal devoted exclusively to Public Archaeology. It is freely distributed online on the Website:

www.arqueologiapublica.es

You can also follow us on:

Blogger:

= http://arqueologiapublica.blogspot.com/

Twitter:

http://twitter.com/APjournal

Facebook:

http://www.facebook.com/group.php?gid=283718532317\&ref=ts 